\title{
Judyta BIELANOWSKA
}

Nicolaus Copernicus University, Faculty of Political Sciences and International Studies, Toruń, Poland

\section{Anita J. Prażmowska, Wtadystaw Gomułka, Warszawa 2016, pp. 295}

W ładysław Gomułka, alias Wiesław, Feliks Duniak (1905-1982) is one of the most controversial figures of the $20^{\text {th }}$ century in the history of Poland, legend of the Polish labour movement and a symbol of the struggle for the preservation of the widest possible independence from the Soviet Union. The period of fourteen years between 1956 and 1970 when he governed as the I Secretary of the Central Committee of the Polish United Workers' Party, which constituted the highest public and political position in the period of the People's Republic of Poland, marks the most sensitive time of political, social, economic and cultural transition in the history of the People's Republic of Poland. It was in connection with Władysław Gomułka that the political and social events of October 1956 took place, when the Polish society for the first time in the history of the People's Republic of Poland demanded to be recognised so forcibly. The fact that Poland became a country of people's democracy more independent from the Soviet Union, and gained geopolitical importance from the point of view of the relationship between the Soviet Union and the West, is attributable to Władysław Gomułka. Last but not least, it was in Władysław Gomulka's time when one of the most tragic events in the history of People's Republic of Poland took place, related to the protests in Baltic coastal cities in December 1970. It is therefore no surprise that, being a person of contradictions not only as a politician, but also as a man, he falls outside any historical or moral classifications, making it difficult for historians, political scientists and sociologists to remain scientifically objective and outline an image of this figure without emotional element or personal involvement.

Many publications of diverse nature have been created about Władysław Gomułka, the character of his governance, relationship with the immediate environment, the social and political system of the 1960s and decision mechanisms of that time. Some of them, especially those of explicitly biographical nature, refer exclusively to Władysław Gomułka and the way 
he was perceived by his co-workers and immediate family. They give an account of his life starting from his birth, then go through political and ideological evolutions until the end of his public activity. Some other publications take the form of an analytical insight into the period of fourteen years of his governance, both domestically and as regards foreign affairs. Another category of publications propose a more synthetic approach in relation to the history of Poland in years 1956-1970, where the figure of Władysław Gomułka and the exercise of public authority were only a background for the events in a broader context.

A book by Anita J. Prażmowska (born in 1950), professor of general history in London School of Economics, Wtadystaw Gomutka: A Biography translated by Katarzyna Skawran, falls into the former category of biographies. The Polish edition was published in 2016 by RM Publishing. It has 295 pages, ten chapters ordered chronologically and in accordance to the issues they present, an epilogue, footnotes, list of abbreviations, bibliography and an index of persons. Already on the basis of the dedication (I dedicate this book to Margaret and Max Morris - communists, pedagogues and, more than anything, my friends), as well as excerpts from an interview with Prażmowska for Focus Historia ("Gomułka was a Polish communist and he thought himself to be an architect of Polish political and social transformations. (...) Those who have an open mind for the history of Poland will learn [from this book] a lot about what governing Poland was like back in the day and on what principles it was based. Those who share the opinion that (...) all those who were in power back then were traitors and Soviet agents, will probably not learn anything as they will not approve of my humanising approach towards
Gomułka"), printed on the back cover of the book, the reader might have presumptions as to what kind of book this is and what subjective attitude the writer has towards the figure she describes. However, it is only the first impression that one may have even before reading the book, as each subsequent chapter carries the reader away from the protagonist of the biography, directing their thoughts to what is generally known in the history of the People's Republic of Poland, and not to the details of Gomułka's life and activity which should, considering the purpose and nature of the work, have priority over side threads.

With the exception of the first chapter, in which Prażmowska provides a detailed account of the conditions of Gomulka's early life and growing up based on source documents, other chapters of the book resemble a textbook of political history of Poland of the $20^{\text {th }}$ century, with a particular focus on the history of the Communist movement and the relationship of its activists with socialists, Trotskyists and other leftist movements. The first part of Gomułka's biography is devoted to the discussion of complex political relations between Poland and the Soviet Union. The name of Gomułka appears in this context only a few times to signal that at that time he was a union activist who was not interested in the Marxism-Leninism doctrine. The question arises about the reason for which the author explains the essence of differing standpoints between Rosa Luxemburg and Vladimir Lenin in such detail, if it had no relevance whatsoever for the political education of Gomułka.

Further, Prażmowska goes on to describe the history of the II World War and the beginnings of People's Republic of Poland against international background. At this juncture, the figure of Gomułka 
comes into the foreground much more frequently, yet the author's deliberations seem to be following two separate tracks, which means that there is no coherence between Wiesław's personal history and the international events. Significantly, such narrative is prevalent throughout the first seven chapters, that is until the year 1956 when Gomulka rose to power in Poland. This leaves only three chapters for the description of his governance, i.e. the most important period from the perspective of his entire life, which is barely enough to present thorough biographical deliberations, where the events of March 1968 and December 1970 were the most appropriate context to present the complexity of Gomułka's personality.

The list of references used by the author is also worth noting. Dominant among them are the sources with reference to the history of the labour movement in Poland and Europe, bibliographical references to foreign policy during the interwar period, historical publications on the selected issues from the period of the People's Republic of Poland and the Soviet Union, as well as the analysis of mutual relations of real socialism countries. Against this background, the original sources that refer strictly to Władysław Gomułka are minimal. Perhaps the inappropriate selection of the sources, plethora of threads unrelated directly to personal and political life of Gomułka cause this work to be derivative, contributing very little to the manner of depicting the analysed figure, not giving enough insight for reflection over who Gomułka really was, which psychological and personality mechanisms played the most vital role in the decisions he made and which personality traits and external factors allowed him to wield power for the longest period, considering all seven I secretaries of KC PZPR.
Anita Prażmowska's book does not comprise an apology or a critical analysis of life and activity of Władysław Gomulka. It seems that in his own biography he plays a secondary role and is only a pretext for a book which is more textbook-like in its nature. At this juncture, it is difficult not to make comparative remarks. In 2014, issued by Czerwone i Czarne publishing house, a book by Jerzy Eisler titled Siedmiu Wspaniatych. Poczet I sekretarzy KC PZPR [The Magnificent Seven. Guide to I Secretaries of the Central Committee of the Polish United Workers' Party] (2014) appeared, which shows the history of each of the seven people who at some point in their career stood on top of the power structure and focused the power of decision in their hands. Contrary to Prażmowska's book, this publication is exciting and gripping, and has the ability to intertwine historical and biographical threads. The figure of Gomułka, which only appears on a few dozen pages, is shown as expressive, tragic, involved in the struggle for his own nation, outstanding and heroic, and at the same time responsible for one of the most tragic events of Polish post-war history.

All of this is missing from Prażmowska's book. In the biography she created, Gomułka was an uncomplicated person who was subject to influence. When undertaking to write a biography of a person who still, regardless of the passing time, arouses controversy and strong emotions in many scientific and influential environments, Anita Prażmowska had an exceptional opportunity to write a unique work and present the subject in a new light. Rich bibliographical source base on Gomulka, his co-workers and the policy he implemented and, more importantly the availability of these sources, have certainly opened a possibility to demonstrate 
the unknown side to this man, those features that humanised him, not only as far as politics was concerned, but also in his private sphere. Unfortunately, Prażmowska missed this opportunity, and her depiction of Gomułka bears no distinctive features as compared with other works that provide an account of his life. What is more, it copies the existing interpretation patterns as far as the evaluation of the People's Republic of Poland is concerned and one of its most notable architects.

\section{References:}

Eisler, J. (2014). Siedmiu Wspaniatych. Poczet I sekretarzy KC PZPR. Warszawa: Wydawnictwo Czerwone i Czarne. 